\title{
Reclaiming Heritage Through the Image of Traditional Habitat
}

\section{Ali Mozaffari and Nigel Westbrook}

\begin{abstract}
From the 1960s, Iran, like many other similar countries experienced a radical urban expansion and industrialization, chiefly as a result of the expanding oil industry. Internal migration fueled by industrialization created both a crisis of habitation and a cultural dissonance, in response to which various schemes were developed for model communities, intended to bridge the gap between Iranian culture, its heritage, and modern urbanism. We will examine one such "model community," New Shushtar, a housing complex adjacent to the ancient heritage town of Shushtar, in which architectural motifs and images were used to evoke and perhaps invoke authentic traditional life. We will place this complex within the broader context in the Muslim world of attempts to defend regional culture from the effects of globalization.
\end{abstract}

Keywords Traditionalism · housing · development · Iran · Shushtar New Town
A. Mozaffari (訩
Deakin University, Geelong, VIC, Australia
Curtin University, Perth, WA, Australia

N. Westbrook

University of Western Australia, Perth, WA, Australia

(C) The Author(s) 2017

T. Rico (ed.), The Making of Islamic Heritage, Heritage Studies in the

Muslim World, DOI 10.1007/978-981-10-4071-9_4 


\section{Introduction: The Mirage of "Islamic Housing”}

In April 1978, the Aga Khan Foundation held its first symposium addressing the question of Islamic architecture and heritage, entitled "Towards an Architecture in the Spirit of Islam." In retrospect, the symposium's theme, which posited the belief in an essential Islamic identity pertaining to the material culture of Muslim societies, could be seen as a significant moment in the construction of an Islamist ideology with reference to architectural heritage. In his opening remarks, the Aga Khan, Prince Shah Karim Hussayni, noted the lack of a common position on what an appropriate architectural idiom for Islamic societies might look like, but also the dynamic social situation that these societies faced in the context of new oil wealth, decolonization, and uneven development. Nonetheless, he argued, there was a necessity for a common Islamic identity and culture (Holod 1980, viii):

Many of these countries have emerged from a colonial era and are searching for an identity of their own. This identity is at the same time specific and regional, yet it must continue to share a common civilization and history with other Islamic countries.

Thus was succinctly stated an inherent contradiction, between a (theologically based) conception of the umma (the unity of world Muslims) and an acknowledgment of cultural differentiation in Islamic societies. In his presentation following these opening remarks-and echoing what would become one of the major idioms of political Islam-Seyyed Hossein Nasr, the influential traditionalist Islamic philosopher, attributed the corruption of Islamic societies to their exposure to Western secular culture and intellectual traditions; this recalled the accusation of Gharbzadegi (Westoxification) of earlier Iranian critical writers toward the cultural change their country was undergoing under the twentieth-century Pahlavi dynasty (Hanson 1983, 2-4). Addressing the theme of the symposium, Nasr's presentation contrasted the ugliness derived from slavish imitation of foreign models with the "serenity and beauty of the traditional Islamic city" (Holod 1980, 1). There should be a return to Islamic traditions in both cultural practices and heritage, an "emergence from darkness into the light" (Holod 1980, 5).

A common theme at this symposium was that architecture constituted a major element of the cultural heritage of Islamic cities. The challenge posed here was to develop principles that might enable new buildings to belong to and constitute that cultural heritage. Janet Abu-Lughod (Holod 
1980, 61-75), for example, argued that the traditional buildings and spaces that constitute the heritage of an Islamic city should serve as models, or an underlying structure, for new developments that respond to the modern culture and economy. Thus, these new habitats might become compatible with traditional heritage, while themselves becoming constitutive of it. Abu-Lughod asserted that preserving Islamic heritage necessitated not only the preservation of significant and typical structures but also the conservation of spatial typologies (e.g., streets, small squares, courtyard housing). Architectural, and thus cultural, identity should be safeguarded by conserving past heritage while adapting habitat for present and future needs; another delegate noted that construction techniques and typologies should be appropriately adapted rather than slavishly follow past models (Holod 1980, 41). In a later article, Abu-Lughod (1987, 172-173) traced the roots of essentialist notions of the Islamic city to French orientalist sources and restricted the intrinsically Islamic characteristics of traditional Muslim cities to three factors: 1. distinction between members of the umma and outsiders; 2. a spatially expressed gender segregation, and 3. a devolved legal system with respect to land claims between residents (Abu Lughod 1987, 162-163). These factors, she argued, did not necessarily have a tangible, material aspect.

In the Third Aga Khan Symposium held in Jakarta in 1979, which was dedicated to the question of housing, Prince Hussayni reiterated his call to remedy a situation in which then-contemporary buildings in Islamic cities failed to "reflect or respond to Islamic tradition, thought or ways of life" (Safran 1980, xi). This type of architecture was to his mind worse than destruction of the past - the two conditions of physical and memorial obliteration resulted in a precarity that had brought the "Islamic World" toward the "brink" of identity loss (Safran 1980, xi) or a loss of cultural memory (Assmann 2011a, 201lb). On the other hand, in the face of rapid change and population growth brought about by processes of modernity, the Prince thought that Islamic forms of housing that accorded with Islamic tradition and custom were, at the time, "unattainable" (Safran 1980, x).

The discontent expressed through such statements reflects both nostalgia for a lost sense of community and concern about a destabilized sense of Muslim cultural identity. This quest for an authentic Islamic habitat, one that reflects and incorporates Islamic heritage, can be detected in both globalizing projects such as the World Heritage Organization (WHO), and in materially embedded processes, such as the local naturalization of syncretically assembled, exotic sources; it involves competing and 
confusing interpretations of tradition (Harrison 2015, 297-312). Thus, does an "Islamic habitat" refer to the embodiment of a continuous tradition? Is it a fictitious fabrication, an act of remembering, or a site of cultural heritage? Certainly, one of the speakers at the Aga Khan Jakarta Symposium, the Iranian architect, Kamran Diba, implied that such a habitat required a continuity with a revered past. Describing his design for housing at Shushtar Now (Shushtar New Town) in Iran, he asserted its maintenance of a "traditional continuity," and a "tightly knit fabric reminiscent of Islamic vernacular architecture" (Safran 1980, 41-45).

Such an essentialist statement fabricates a unitary and immutable cultural identity in which present-day cultural productions derive their value through continuity with the surviving heritage of the past. In the following discussion, we will interrogate and historicize such attempts to "reclaim heritage," by building on recent concepts of remembering, tradition, heritage, and their instabilities, to then trace the genealogy of the idea of Muslim habitat. We will argue that this concept is a product of a global tendency that developed out of Western colonial and postcolonial policies and critiques, through which European modernist, technologically advanced theories of urban and regional planning were adapted and broadened to accommodate the new perspectives of sociology and anthropology in response to what was perceived to be a gradient of cultural evolution. We will further problematize the very notion of Islamic heritage in architecture, arguing that such works as Shushtar No'w may be considered as heritage, not because of some essentially Islamic character, but rather for their capacity to engender the construction of belonging-a sense of place-through evocation of traditions, images, and familiar spatial experiences, where "the past is used to legitimate a new practice, not an existing one" (Otto and Pedersen 2005, 29).

\section{Probing an Islamic Tradition in Architecture and Habitat}

The discourse of a purported Islamic heritage, as expressed through architecture and, more specifically, the idea of Islamic housing and habitat, may be explained in part through a process of memory restitution. Here, the medium of design plays an important role in coalescing, routinizing, socializing, and potentially globalizing practices, symbols, and beliefs incorporated in the "myth" of Muslim housing. Therefore, an examination of the establishment and transmission of an Islamic tradition in architecture is a process that must pay attention to both content, that which is handed 
down (Otto and Pedersen 2005, 22), and form, the manner of handing down. It is argued here that transmission of an Islamic heritage lies in transactions between two categories-Muslim memories and Muslim heritages - which help to frame how an Islamic habitat discourse and its heritage might be formed in dialogue with cultural memory.

The dramatic shifts and disruptions of social structures in most Muslim societies since the late nineteenth century, and most critically in the 1960s and 1970s, following successive Arab-Israeli wars, problematize this process. The undermining of political secularism and a rise of Islamic nationalism formed the context for the idea of the need for an authentic Islamic tradition and heritage in architecture and urbanism (Dorraj 1999, 237; Juergensmeyer 1993, 12). The attempt to revive and institutionalize such traditions by powerful individuals like the Aga Khan, and groups or even states, such as Iran after 1979, was based on their assumption or hope that their Muslim audiences would be willing to subscribe to the new memories and customs, or could be coerced into the routines, in part secured through the global rise of political Islam.

At the heart of this turn to tradition is the desire to construct a modern Muslim identity. ${ }^{1}$ Once taken up by Islamist discourses in a Muslim society, a habitat ascribed as Muslim can in itself become a "site of memory" (Nora 1989, 7-24). That is to say, it can be an indication of an ethnoreligious, nationalist tendency as well as operating on a more functional-meaning lived and experienced-level of memory. In the traditional village, a semblance of timelessness was maintained by a slowly evolving symbiosis between place, economy, and culture; however, as it was drawn into a globalized economy and new sources of work were created in urban centers, this rhythm was disrupted by the internal migration of rural populations to the city fringes. It is in response to this historical and economic context that governmental policies were developed in both European colonies and emergent Middle Eastern nations, for the creation of a new habitat appropriate for these populations, one that could bridge the traditional and modern worlds.

\section{Housing The “Indigenous" in French North Africa}

Arguably, the discourse of "Islamic housing" may be traced back to the ameliorative colonial policy concerning so-called indigenous housing and settlements developed in the French protectorate of Morocco from 1912 to 1925 under Resident-General Marshal Lyautey. Lyautey sought to 
protect the fabric and spatial structure of traditional settlements such as the casbah of Casablanca, which were beginning to be perceived to possess heritage value given their embodiment of cultural traditions (Rabinow 1989, 277-319). These settlements were seen to have developed out of such traditional social practices as the clan structure, seclusion of women, the waqf (religious endowment) system, and adaptation to local climatic conditions. On the other hand, the similarity of building forms and spaces in the Jewish and Muslim quarters did, however, call into question an intrinsically Islamic habitat. Lyautey's preservationist policies did little to solve the problems of internal migration, and the formerly organic and cohesive urban structure of the old urban cores became subject to massive overcrowding, often by new residents with few cultural links to the traditional inhabitants, the merchant elite, and poorer artisans. The formerly unitary spatial and social structure was thus disrupted (Cohen and Eleb 1998, 214-226).

In subsequent years prior to the Second World War, public and company housing estates for Muslims, such as the Habous quarter, were laid out in Casablanca to the design of French architects. Their external appearance was of traditional, walled towns, while the domestic layouts drew on the typology of courtyard gardens, fountains, and flexible living rooms (Cohen and Eleb 2002, 214-226; Cohen 2006; Eleb 2000; Falehat 2014). The intention was to provide habitat, including both housing and neighborhood structure, which was appropriate for the residents' social norms and religious practices, while the picturesque urban décor also served to support a growing touristic market for local color, supplementing the old casbah.

Scholars have also noted an imperialist and self-reflective agenda in this citation of traditional forms and spaces (Fuller 2008; Yacobi and Shadar 2014, 975-997). With the influence of modernist architectural ideas emphasizing simple stereometric forms, settlements like the casbah were revalued for their simple, cohesive cubic form, which were appropriated by French architects, both to house the colons (the European colonists, both French and other nationalities), and eventually for housing the "indigenous peoples"-Arabs, Berbers, and Jews. The architect of the Habous quarter, Albert Laprade, described the new style of Lyautey's projects as a "synthesis of our Latin spirit and love for autochthonous art" (Cohen and Eleb 2002, 150, cited in Fuller 2008, 978-979). This statement reflects a prevalent discourse of what has been described as "Mediterraneanism," in which a linkage was made to the ancient culture of Greece and Rome; the Arab village was regarded as a (primitive) 
descendent of this culture, of which the French were regarded as the inheritors. Through this mythologization of the Mediterranean, the recent history of the Ottoman Empire was elided (Fuller 2008, 984). Thus, cultural memory was fabricated on several levels, that of the Islamic, but also that of Jewish colonized subjects and of the colonizers.

In the post-Second World War period of economic expansion in French North Africa, and in response to the internal migration of "indigenous peoples," multidisciplinary teams of French architects and planners proposed that the discussion of mass dwelling should be undertaken under the rubric of "habitat," an organic and interconnected relationship between diverse urban activities and functions, rather than under that of "mass-housing" (Cohen and Eleb 2002, 325). This notion of "habitat," was probably first promulgated by the leading French architect, Le Corbusier, in relation to his Marseilles Unité d'babitation (1947-1952Unity of Habitat); it was distinguished from the earlier modernist category of housing (Mumford 2000) and built on both geographers' studies of space and land-zoning and anthropologists' studies of the way in which certain social practices, both everyday and exceptional, evolved in relation to particular climatic and geographical contexts to produce cultural specificity. And yet the new term, "habitat," with its reference to a grounded culture, contained an inherent contradiction, given that the "progressive" architects of the Congrès international d'architecture moderne (CIAMInternational Congress of Modern Architecture) were committed to universal standards of enlightened civilization. The design of culturally specific habitats was rather conceived of as a necessary bridging infrastructure for populations whose cultural development was deemed to be insufficient to successfully embrace the more advanced Western secular culture (Eleb $2000,55 \mathrm{ff})$.

The director of planning in French Morocco, Michel Écochard, proposed the provision of housing settlements for "indigenous peoples" based on the concept of what he termed "secular customs"; these were seen to consist of the secluded space of the family and clan, the gendered space of male-female interactions, and the pronounced cultural division between interiority and exteriority, together with the social spaces of the bazaar and mosque (Cohen and Eleb 1998, 332-335; Eleb 2000, 56-61). Écochard's policy of housing based on secular customs reflected the real cultural differences not just between Europeans and "indigenous peoples" but also between the largely Berber rural populations and the urbanized Arabs of the coastal cities. However, some of the behavioral and cultural 
norms constituting Écochard's secular customs, such as patterns of spatial use, ideas of privacy, and spatial hierarchies, crossed ethnic and religious boundaries, as Abu-Lughod has noted (1987, 161).

Under Écochard's guidelines, a predominantly horizontal housing layout-closer to a traditional village structure and scale-was felt appropriate for the most "socially backward" populations. The ATBAT-Afrique settlements, notably the Carrières Centrales designed by a team led by Candilis, under Écochard's direction (Avermaete 2005), featured shaded pedestrian streets and private courtyards onto which opened one to three optimally south-facing rooms, a typology that was thought to respond to the gendered space of traditional Arab and Berber Muslims, but also followed the French colonial model of a Mediterranean habitat (Écochard 1955 cited in Eleb 2000, 56). However, as stated above, this spatial structure was conceived of as a bridge between the "static" culture of traditional Islamic societies and the enlightened one of modern rational society (Eleb 2000, $59) .{ }^{2}$ In 1953, this project was presented by Écochard and the co-designer, Candilis, to the Ninth Congress of CIAM at Aix-en-Provence, as an example of the new paradigm of "habitat," for which it formed a strong stimulus (Mumford 2000, 234). The paradigm fully emerged at the 1970-1976 Architectural Congresses in Iran, where leading international figures, including Écochard and Candilis, met to debate an appropriate habitat for that Islamic nation (Bakhtiar and Farhad 1970, 249-250).

\section{Designing for Cultural Continuity: Shushtar No'w, Iran}

Underpinning the new concept of "habitat" was both a dismissal of abstract planning structures, in which housing was seen to have been secondary to zoning diagrams, and a belief in the ability of the architectural form and space of social housing to provide the scaffolding for authentic forms of social life and community to develop. In the same period, authorities in developing countries, such as Iran, similarly grappled with the problem of how to create culturally authentic habitat in the face of similar problems of population displacement and housing shortages in the cities - the byproducts of processes of modernization.

The 1970s oil economy of Iran, and its associated rapid modernization, had the negative consequence of a population displacement from rural villages to larger industrial cities and towns (Mahdavy 1965). This, as Diba observed, fueled the growth of squatter housing and escalated socioeconomic problems (Safran 1980, 38). Faced with this crisis, the government 
initiated a centrally planned housing program that considered a range of potential solutions, including the importation of factory-made, prefabricated housing - a key topic of the 1970 First International Congress of Architects in Iran, held in Isfahan (Westbrook and Mozaffari 2015). In the following 1974 Congress in Persepolis, a motion was carried that the Iranian government should commission the design of model housing projects, embodying the new concept of "habitat." Of the subsequent government-funded model housing communities, the most paradigmatic project was the company housing complex Shushtar No'w (New Shushtar), near the historic city of Shushtar in Khuzestan. The commission was awarded in 1975, a year after the Persepolis Congress, to Kamran Diba's firm DAZ Architects, Planners, and Engineers (Shirazi 2013). ${ }^{3}$ The outcome was one of the most celebrated and publicized examples of new town design in the developing world, as reflected in numerous journal publications, and its appearance on the cover of the 1990 volume of the Aga Khan Awards Foundation (Powell 1990). In 1986, it received an Aga Khan Commendation, the first-stage design having been approved by 1977, and completed in 1980, after Diba's departure from Iran.

The design for Shushtar No'w was based on an attempt to reinterpret the appearance and structure of traditional towns in the region, and specifically the ancient towns of Shushtar, and using narrow alleyways that would provide shade and habitable roofs to permit sleeping on the roofs during hot summer nights (Fig. 4.1). ${ }^{4}$ The project was praised by the 1986 Aga Khan Award panel for its having remained "faithful to the tradition, customs, ambitions and needs of the people of a region through an architecture expressing these aspirations and engendering balance and harmony," for creating and facilitating a sense of community through its spatial network and for establishing a meaningful formal and spatial dialogue with the old city of Shushtar (Serageldin 1989, 165).

For the Aga Khan Awards panel, Shushtar No'w appeared as an intentionally unified cultural project that effected a continuity with traditional local vernacular architecture through its materiality and spatial network. The jury chairman noted the need to deal, in such projects, with "the special values of traditional societies" (Serageldin 1989, 69). This is similar to the call in the 1974 Persepolis Architects Conference-at which Écochard and Candilis were both invited delegates-for the creation of housing that responds to the desirable diversity of perceptions and means inherent in "the shaping of the human habitat in time and place" (Bakhtiar $1974,360)$. Indeed, in many respects the design is responsive to its local 


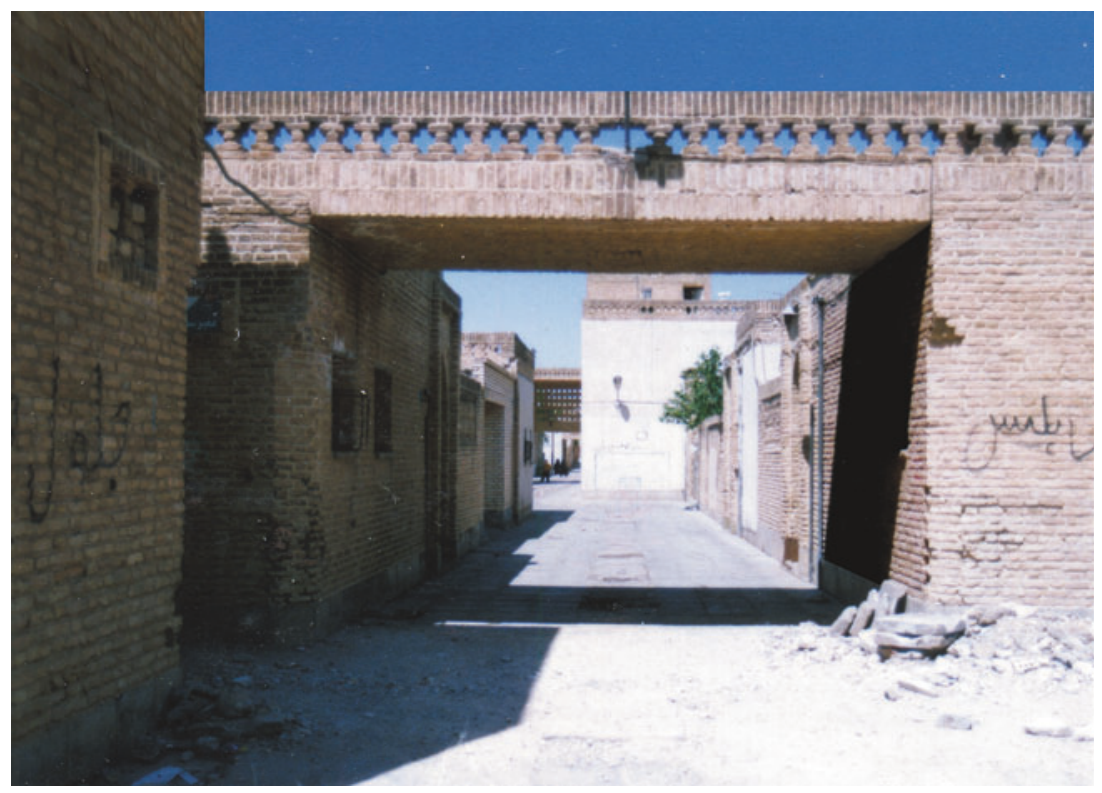

Fig. 4.1 A pedestrian walkway in Shushtar No'w, development stage 1 (Photograph by Ali Mozaffari, 1993)

context. Thus, rather than following the modern functional program of a house, the layout of apartments is derived from spatial units of rooms which are all of a larger-than-typical size; this permits functional flexibility, akin to the traditional diurnal and seasonal variations in spatial use within the house, as well as consisting of two zones separating private family area from external and socializing areas. Second, like the ATBAT-Afrique housing, there is a hierarchy of courtyards from individual, to community and urban scale. The brick walls and vaulted roofs and internally oriented openings shield against the harsh sunlight and privilege the courtyard garden, while providing a culturally appropriate social seclusion. Finally, the design was consciously based on a sociological study of the way in which people in nearby towns interacted in public and private space (Shirazi 2013, 36).

But the most noticeable aspect of the project is its citation of a lexicon of selected images of traditional architecture. The urban configuration is 
based, in Diba's words $(1980,4)$, on the concept of a fire temple courtyard occupying the highest part of the hill, and forming an axial center for two broad spines of open space at right angles to each other, thus forming a configuration similar to that of a traditional Persian garden, or ChaharBagh (fourfold garden). This indeed invokes aspects of cultural memory from various historical periods, asserting a common pattern of spatial culture for a considerable duration of time, presumably with the objective of preserving them as functional memory. In this regard, it can be argued that Diba's action is one of heritage preservation. In the original design, the axial spines were extensively landscaped as a series of shady garden rooms, while in each of the four resultant quadrants, narrow, shaded pedestrian streets connect to local neighborhood courtyards, or maidanche, and are abutted by blocks of courtyard houses separated by lanes stepping down the hill, recalling the traditional residential quarters, or maballeh. While the design is undoubtedly influenced by the projects presented at the Iran Congresses, notably the North African housing, the built project conveys an image that resonates with its traditional context: Lattice-brickwork bridges frame the residential streets at points adjacent to neighborhood courtyards (Fig. 4.2), recalling similar details in the nearby town of Dezful where Diba had undertaken a master plan, ${ }^{5}$ while the central pedestrian spine of the master plan is reminiscent of the Isfahan bazaar plan. The overall layout is a constructed image of unity.

The desired unity at New Shushtar was effected, we would argue, through the montaging of reassuring images, in support of a desired connection to traditional habitat. In this respect, it is proposed that, rather than constituting a continuity with tradition, the project is a product of modern techniques, in which aspects of traditional buildings and towns have been cited, while figures and images have been appropriated from Western sources, most evidently the subcontinental work of the widely influential American architect, Louis Kahn, who was a key figure at the 1970 Congress in Isfahan. ${ }^{6}$ In an interview we conducted, Diba's former associate, Kashanijoo, noted that the intention was to design a "total environment," a notable theme of the Iran Congresses, ${ }^{7}$ where in 1970, the Iranian-American architect, Nader Ardalan, supported by Kahn, had called for the conscious embrace of a unitary concept of culture in which material and spiritual worlds were in harmony (Bakhtiar and Farhad 1970, $31-44)$. This idea of an authentic culture found its image in the form of the traditional village or town, for which Isfahan served as a spectacular model. Indeed Diba, at the Third Aga Khan Congress in Jakarta, 


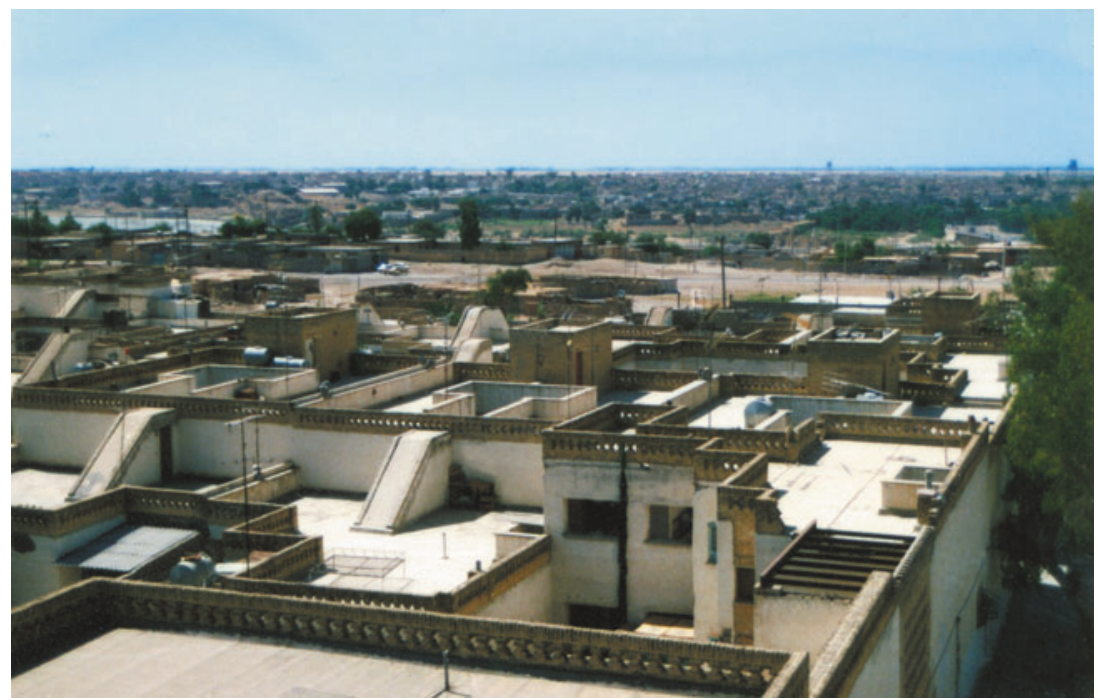

Fig. 4.2 General view of Shushtar No'w rooftops, development stage 1 (Photograph by Ali Mozaffari, 1993)

characterized his own design for Shushtar No'w as maintaining a continuity with Iranian traditions in its construction and spatial structure (Safran 1980, 41-44). The model for such desired continuity was the traditional house, village, and city (Bakhtiar 1974, xvii).

\section{Conclusion}

The dynamic relationship between habitat and social space raises a significant question for discussions of a putative Islamic heritage. Might intentionally designed projects of local and "Islamic" architecture, through the habitualizing of particular spatial performances - or through repetition-constitute in time, both an "invented tradition" (Hobsbawm 1983) and, consequently, heritage? But perhaps the more pertinent question here is to ask, following Thomas (1992, 216), "against what are traditions invented?" In the context of this chapter, this Other-that which is not heritage-is the process of globalization and economic and demographic transformation allegorized as "Western culture," the symptoms of which are uneven development, displacement, and 
industrialization. In the discourse of the Aga Khan Awards symposia, the Other was seen to endanger a precious heritage, and in reaction to which the traditional city was incapable of adapting. Processes of globalization are therefore deeply implicated in both creating and questioning the notion of "Islamic Heritage."

As we have argued in this chapter, putative Islamic authenticity in architecture travels from housing projects for the "indigenous" in French colonial North Africa to the town of Shushtar Now in Iran through a process whereby well-placed local actors-in our case, the Empress Farah Diba and the organizers of the Iranian Congresses of Architects, notably her cousin Kamran Diba-invited the participation of leading architects and planners to present their perspectives, which could lead to collaborations on model projects. As outlined earlier, one such example of a model project was Shushtar No'w. In turn, this project, which owed much to its colonial models, was embraced by the Aga Khan Foundation as a paradigmatic example of Islamic housing. This project drew on the heritage of existing towns, creating familiar memories through the assemblage of the "thick images" of decorative motifs, screening and shading structures, courtyard buildings, narrow pedestrian streets, and a simulated bazaar structure, through which a "continuity" with the Islamic heritage of Iran was attempted. This process worked on the ground since it remained unquestioned, and from the outside it was confirmed by the reception it received from proponents of Islamic identity and heritage.

Through its play of images and motifs, Shushtar No'w also served a didactic role; a substantial proportion of the intended residents were of nomadic origins who were being encouraged to settle and had little or no experience of urban or perhaps even village life. While they shared religious and social values with the local population, their encounter with the habitat of Shushtar No'w was one-as in North Africa- of acculturation where, we would argue, the construction of social memory was effectively attempted. For the new residents, perhaps, a form of communicative memory (the unofficial and quotidian) could be engendered through the repetitive activities and rituals of everyday (Erll 2011, 28). But can this processual memory be stated as evidence of an essential Islamic heritage and identity? We would argue that such identity has been ascribed to objects and spaces that have a syncretic formation. The discourse of "Islamic habitat" as exemplified by the Aga Khan Awards and Shushtar No'w in particular is connected to and paralleled by that of the Islamic city. 
Both are linked to the same narratives of political Islam that would become dominant from the early 1980s. It may be true that the universalized idea of the Islamic city as such is a French (or in another narrative, American) Orientalist invention (Aldous 2013). But there is, so far, little that explains the currency of this invention beyond Western scholars and indeed among broad sectors of Muslim intelligentsia around the globe, in which the narrative of the Islamic city and its heritage are presented as a fait accompli. Such a rise in interest in Islamic heritage could reasonably be explained through globalizing processes. As scholars in the field have correctly observed, this interest is a symptom of, among other things, the intertwined projects of modernity and globalization (Anheier and Yudhishthir 2011; Appadurai 1996; Beck 2000; Tsing 2005). Heritage is a globalizing project (Harrison 2015), one which has been brought forth through the growing interconnectedness of various areas of politics, culture, and economy, together with various modes of circulation of things and ideas; it operates on the three arenas of politics, economy, and culture and is facilitated through travel and technological advancements such as communications.

The rising interest in the Islamic city, not as a museum, but as a living emplacement of cultural heritage, arises from this type of circulation of material (in this case, housing), people (those working in the colonies or even as contractors in the developing world), and ideas (the Islamic city itself) - a process of "design" that is globalizing, comprised of modern education and techniques, in which a dialogical relationship between the present and the past is constructed. However, in this increased exposure to the Other, and a consequent increase in multivocality and diversity, there has arguably developed a growing sense of discontinuity with the past, a rupture (following Appadurai and Harrison) that has heightened the significance of heritage, and has resulted in "a series of material and discursive interventions which actively remake the world in particular ways" (Harrison 2015, 297). The Islamic habitat and architecture discourse is but one such instance. Instead of creating uniformity, globalization also creates "frictions," from which arise various discourses of identity. Thus, for example, the moving feast of the Aga Khan Symposia (beginning incidentally in France) was itself part of this circulation and an attempt at creating an Islamic world.

But, as our examples in North Africa and Iran have suggested, the Islamic architecture discourse is also born of specific conditions on the ground: the movement of people resulting from processes of modernization; the type of 
material, as this too gives a certain look or experience; and the available technologies-hence the line of discussion about technology and tradition in the 1970s Iranian Congress series-which also determine what can be built. Through these contingencies, a processual social memory, and a similarly processual heritage result which, following Harrison, we would argue is the outcome of something akin to a design process, a fabrication, and is materialized on the ground as such (Harrison 2015). This product of "design" amounts to the heritage itself, the concretization of memory. From this perspective, it is possible to reconsider our example of Muslim habitat at Shushtar No'w, notwithstanding its evident syncretic basis, as drawing on both imagistic assemblages of traditional settlements and modern conceptions of mass housing, in order to constitute through its design a habitat in which certain cultural traits could be preserved and prolonged. This prolongation, the objective behind Diba's design, which he characterized as a project of cultural continuity, is, we would argue, a dialogue with the past through the medium of design in order to shape the present and can thus be defined as a modern heritage process. This thus raises the issue of whether Shushtar No'w and projects of its ilk are worthy of consideration for their heritage value, not because they are examples of Islamic heritage but because they are the heritage product of global processes.

\section{Notes}

1. The fabrication of a modern Islamic identity is beyond the focus of this chapter but is discussed, for example, in Enyat, Modern Islamic Political Thought and Mozaffari, Forming National Identity in Iran: The Idea of Homeland Derived from Ancient Persian and Islamic Imaginations of Place.

2. The architects working under Écochard were both French and native-born Moroccan and included Georges Candilis and Shadrach Woods, both of whom had worked for Le Corbusier on the Unité d'habitation at Marseilles (1947-1952) and were co-founders of ATBAT-Afrique in Casablanca. Écochard and Candilis would be influential delegates at the 1974 Persepolis Architectural Congress.

3. Kashanijoo, Ahmad. Interview by Ali Mozaffari. Online. NovemberDecember 2014. Noorheyhani, Hamid. Interview by Ali Mozaffari. Online. November-December 2014.

4. Kashanijoo, Ahmad. Interview by Ali Mozaffari. Online. NovemberDecember 2014. Noorheyhani, Hamid. Interview by Ali Mozaffari. Online. November-December 2014. 
5. Kashanijoo, Ahmad. Interview by Ali Mozaffari. Online. NovemberDecember 2014. Noorheyhani, Hamid. Interview by Ali Mozaffari. Online. November-December 2014.

6. The Jewish American architect, Louis Kahn, was highly influential on the development of a discourse of Islamic architecture through his commissions in India and Bangladesh, notably the Indian School of Management at Ahmedabad, and the National Parliament complex at Sher-e-Bangla in Bangladesh. Notoriously, the latter building was denied an award by the inaugural Aga Khan awards panel, ostensibly because of its cultural distance from its constituency.

7. Kashanijoo, Ahmad. Interview by Ali Mozaffari. Online. NovemberDecember 2014. Noorkeyhani, Hamid. Interview by Ali Mozaffari. Online. November-December 2014.

\section{BibliOgRAPHY}

Abu Lughod, Janet L. 1987. “The Islamic City: Historic Myth, Islamic Essence and Contemporary Relevance." International Journal of Middle East Studies no. 19 (2): 155-176.

Aldous, Gregory. 2013. "The Islamic City Critique: Revising the Narrative." Journal of the Economic and Social History of the Orient no. 56 (3): 471-493.

Anheier, Helmut K., and Raj Isar Yudhishthir 2011. Cultures and Globalization: Heritage, Memory and Identity. London: SAGE Publications.

Appadurai, Arjun. 1996. Modernity at Large. Minneapolis: University of Minnesota Press.

Assmann, Aleida. 2011a. Cultural Memory and Western Civilization: Functions, Media, Archives. Cambridge: Cambridge University Press.

Assmann, Jan. 2011b. "Communicative and Cultural Memory." In Cultural Memories: The Geographical Point of View, edited by Peter Meusburger, Michael Heffernan, and Edgar Wunder, 15-27. Heidelberg, Germany: Springer.

Avermaete, Tom. 2005. Another Modern: The Post-War Architecture and Urbanism of Candilis-Josic-Woods. Rotterdam, The Netherlands: Nai.

Bakhtiar, Laleh. 1974. Towards a Quality of Life: The Role of Industrialization in the Architecture and Urban Planning of Developing Countries. Report of the Proceedings of the Second International Congress of Architects, Persepolis, Iran. Tehran: Hamdami Foundation.

Bakhtiar, Laleh, and Leila Farhad 1970. The Interaction between Tradition and Technology. Report of the Proceedings of the First International Congress of Architects, Isfaban, Iran. Tehran, Iran: Ministry of Housing and Urban Development.

Beck, Ulrich. 2000. What Is Globalization?. Cambridge: Polity.

Cohen, Jean-Louis. 2006. "Architectural History and the Colonial Question: Casablanca, Algiers and Beyond." Architectural History no. 49: 349-372. 
Cohen, Jean-Louis, and Monique Eleb 1998. Casablanca: Mythes et Figures d'une Aventure Urbaine. Paris: Hazan.

Cohen, Jean-Louis, and Monique Eleb 2002. Casablanca: Colonial Myths and Architectural Ventures. New York: Monacelli Press.

Diba, Darab. 1980. Architect's Design Report: Aga Khan Technical Review Summary. Philadelphia, PA: Aga Khan Award for Architecture 1986.

Dorraj, Manochehr. 1999. "The Crisis of Modernity and Religious Revivalism: A Comparative Study of Islamic Fundamentalism, Jewish Fundamentalism and Liberation Theology." Social Compass no. 46 (2): 225-240.

Écochard, Michel. 1955. 'Habitat musulman au Maroc,' L'Architecture d'Aujourd'hui 60: 36-40.

Eleb, Monique. 2000. "An Alternative to Functionalist Universalism: Écochard, Candilis, and ATBAT-Afrique." In Anxious Modernisms: Experimentation in Postwar Architectural Culture, edited by Sarah Williams Goldhagen and Rejean Legault. Cambridge, MA: Massachusetts Institute of Technology Press.

Erll, Astrid. 2011. Memory in Culture. Hampshire, UK: Palgrave Macmillan.

Falehat, Somaiyeh. 2014. "Context-Based Conceptions in Urban Morphology: Hezar-Too, an Original Urban Logic?" Cities no. 36: 50-57.

Fuller, Mia. 2008. "Mediterraneanism: French and Italian Architects-Designs in 1930s North Africa Cities." In The City in the Islamic World, edited by Renata Holod Salma, Khadra Jayyusi, Attilio Petruccioli, and André Raymond. Leiden, Netherlands: Brill.

Hanson, Brad. 1983. "The 'Westoxication' of Iran: Depictions and Reactions of Behrangi, Al-E Ahmad and Shari Ati'." International Journal of Middle East Studies no. 15 (1): 1-23.

Harrison, Rodney. 2015. "Heritage and Globalization." In The Palgrave Handbook of Contemporary Heritage Research, edited by Emma Waterton and Steve Watson, 297-312. Basingstoke, Hants, UK: Palgrave Macmillan.

Hobsbawm, Eric. 1983. "Introduction: Inventing Traditions." In The Invention of Tradition, edited by Eric Hobsbawm and Terence Ranger, 1-14. Cambridge: Cambridge University Press.

Holod, Renata. 1980. Toward an Architecture in the Spirit of Islam, Proceedings of Seminar One, Architectural Transformations in the Islamic World, Aiglemont, Gouvieux, France, April 1978. Philadelphia, PA: Aga Khan Awards.

Juergensmeyer, Mark. 1993. The New Cold War? Religious Nationalism Confronts the Secular State. Berkeley: University of California Press.

Mahdavy, Hossein. 1965. "The Coming Crisis in Iran.” Foreign Affairs.

Mozaffari, Ali. 2014. World Heritage in Iran: Perspectives on Pasargadae. Farnham, Surrey, UK: Ashgate.

Mumford, Eric 2000. The CIAM Discourse on Urbanism. Cambridge, MA: Massachusetts Institute of Technology Press. 
Thomas, Nicholas. 1992. 'The inversion of tradition', American Ethnologist no. 19 (2) May: 213-232.

Nora, Pierre 1989. "Between Memory and History: Les Lieux de Mémoire." Representations, Special Issue: Memory and Counter-memory no. 26: 7-24.

Otto, Ton, and Poul Pedersen 2005. Tradition and Agency: Tracing Cultural Continuity and Invention. Aarhus: Aarhus University Press.

Powell, Robert 1990. The Architecture of Housing. Singapore: Concept Media, The Aga Khan Award for Architecture.

Rabinow, Paul. 1989. French Modern: Norm and Forms of Social Environment. Cambridge, MA: MIT Press.

Safran, Linda. 1980. "Housing Process and Physical Form." In Housing Process and Physical Form, Proceedings of Seminar Three, Architectural Transformations in the Islamic World, Jakarta, Indonesia, edited by Linda Safran, March 26-29, 1979. Philadelphia, PA: Smith, Edwards, Dunlop.

Serageldin, Ismail. 1989. Space for Freedom: The Search for Architectural Excellence in Muslim Societies. London: The Aga Khan Award for Architecture, Butterworth Architecture.

Shirazi, Reza M. 2013. "From 'Shustar No' to 'Shahre Javan Community'." Young Cities Research Paper Series, T.U. Berlin no. 7.

Tsing, Anna. 2005. Friction: An Ethnography of Global Connection. Princeton, NJ: Princeton University Press.

Westbrook, Nigel, and Ali Mozaffari. 2015. A Return to the Beginnings of Regionalism: Shushtar New Town Seen in the Light of the 2nd International Congress of Architects, Persepolis, Iran 1974. Paper read at SAHANZ: Architecture, Institutions and Change-Proceedings of the Society of Architectural Historians, Australia and New Zealand, 7-10 July at Sydney.

Yacobi, Haim, and Hadas Shadar 2014. "The Arab Village: A Genealogy of (Post) colonial Imagination." The Journal of Architecture no. 19 (6): 975-997.

Ali Mozaffari is research fellow at Alfred Deakin Institute, Deakin University and adjunct research fellow at the Australia-Asia-Pacific Institute, Curtin University, Australia. He is the founding coeditor of the book series Explorations in Heritage Studies (Berghahn) and author of World Heritage in Iran; Perspectives on Pasargadae (Routledge 2016).

Nigel Westbrook is associate professor and associate dean (Research) at the University of Western Australia, lecturing in the areas of architecture and urban design, architectural history, and urban studies. His research interests include the sixteenth-century Lorichs panorama of Istanbul, the Byzantine Great Palace and its urban context in Constantinople, and modern Iranian architecture. 
Open Access This book is licensed under the terms of the Creative Commons Attribution 4.0 International License (http://creativecommons.org/licenses/ by $/ 4.0 /)$, which permits use, sharing, adaptation, distribution and reproduction in any medium or format, as long as you give appropriate credit to the original author(s) and the source, provide a link to the Creative Commons license and indicate if changes were made.

The images or other third party material in this chapter are included in the chapter's Creative Commons license, unless indicated otherwise in a credit line to the material. If material is not included in the chapter's Creative Commons license and your intended use is not permitted by statutory regulation or exceeds the permitted use, you will need to obtain permission directly from the copyright holder. 